\title{
State Taxation of Interstate Commerce: Roadway Express, the Diminishing Privilege Tax Immunity, and the Movement Toward Uniformity in Apportionment
}

Under the prohibition of the commerce clause, ${ }^{1}$ an enterprise engaging in exclusively interstate business within a state has traditionally enjoyed immunity from a state tax imposed on the privilege of doing business in the state. ${ }^{2}$ It is this constitutionally protected subject of the tax, the privilege, which is the basis of the immunity; ${ }^{3}$ the measure, at least in theory, has not presented constitutional questions, ${ }^{4}$ although the Supreme Court has on occasion given the measure of a tax constitu-

1 See Pensacola Tel. Co. v. Western Union Tel. Co., 96 U.S. 1 (1878); Developments in the Law-Federal Limitations on State Taxation of Interstate Business; 75 Hakv. L. Rev. 953, 1031 (1962) [hereinafter cited as Developments].

2 Memphis Steam Laundry Cleaners, Inc. v. Stone, 342 U.S. 389 (1952); Spector Motor Service, Inc. v. O'Connor, 340 U.S. 602 (1951); State Tax Comm'n of Mississippi v. Interstate Natural Gas Co., 284 U.S. 41 (1931); Alpha Portland Cement Co. v. Massachusetts, 268 U.S. 203 (1925); Atlantic \& Pacific Tel. Co. v. Philadelphia, 190 U.S. 160 (1903). See P. Hartman, State Taxation of Interstate Commerce 103, 104 (1953); J. Hellerstein, State and Local Taxatron 193, 194 (2d ed. 1961). For a consideration of the early cases see Powell, Indirect Encroachment on Federal Authority by the Taxing Powers of the States, 31 HARv. L. REv. 572 (1918) and Hellerstein, State Franchise Taxation of Interstate Businesses, 8 LAw. Guild REv. 429 (1948). The term privilege tax as used in this comment refers to any tax, regardless of its measure, whose subject is the privilege of doing business in a state or some variant thereof such as the privilege of doing business in corporate form in a state. Professor Hartman has described the variety of levies that may be referred to as a privilege tax: "The term 'privilege tax' as employed by the Supreme Court is somewhat generic and has no fixed or definite meaning. It is given all sorts of appellations and is imposed for the enjoyment of all sorts of privileges. It may be termed a franchise tax, or called an excise for the privilege of engaging in certain activities; or the nomenclature may couple 'franchise and excise.' . . The 'privilege tax' may be an excise on the privilege of using an article, or the exaction may be tagged an occupation tax, or a license fee, or simply designated a tax for the privilege of enjoying various sorts of business activities. . . " P. Hartman, State Taxatron of Interstate Commerce 97-8 (1953).

3 Atlantic \& Pacific Tel. Co. v่. Philadelphìa, 190 U.S. 160 (1903). The Court said: "No state can compel a party, individual, or corporation to pay for the privilege of engaging in interstate commerce." Id. at 162.

4 Home Ins. Co. v. New York, 134 U.S. 594, 600 (1890). See also Atlantic Refining Co. v. Virginia, 302 U.S. 22, 26-7 (1937); Kanisas City, F.S. \& M. Ry. v. Botkin, 240 U.S. 227, 233 (1916); Baltic Mining Co. v. Massachusetts, 231 U.S. 68, 87 (1913); P. Hartman, State TAXatyon of Interstate Commerce 114 (1953).

186 
tional significance by obscuring the distinction between subject and measure. 5

In 1959 the Supreme Court handed down a landmark decision in Northwestern States Portland Cement Co. $v$. Minnesota, ${ }^{6}$ holding that the commerce clause was no bar to a nondiscriminatory, fairly apportioned net income tax imposed on a foreign corporation engaged exclusively in interstate commerce in the taxing state. At the same time, the Court reaffirmed Spector Motor Service $v . O^{\prime}$ Cannor, ${ }^{7}$ in which it had invalidated a Connecticut tax imposed on such a corporation, the tax having been measured by net income but levied on the privilege of doing business in the state. Given the holding of Spector, that the commerce clause forbids the imposition of a state privilege tax-irrespective of its measure-upon a corporation engaged exclusively in interstate business within the state, ${ }^{8}$ the Northwestern decision, by its approval of an impost levied on and measured by income derived from exclusively interstate activity, gave constitutional weight to a distinction between subject and measure which no longer had any economic significance. Since the measure of the tax invalidated in Spector ${ }^{9}$ was

3 See, e.g., Gwin, White \& Prince, Inc. v. Henneford, 805 U.S. 434, 438-40 (1939); New Jersey Bell Tel. Co. v. State Board of Taxes, 280 U.S. 338 (1930).

The subject is the legal incidence of a tax. It is the thing or event upon which the power to tax is based; the measure of a tax is the yardstick to which the rate is applied. Subject and measure may be distinct as in a privilege tax where the subject is the privilege and the measure is, for example, income; or subject and measure may coincide as in an income tax where the income is both the subject upon which the tax power is predicated and the basis upon which the amount due is calculated. See Hartman, State Taxation of Corporate Income Fram a Multi-State Business, 13 VAND. L. REv. 21, 49, 50 (1959); Developments, 75 HARV. L. REv. 953, 960 (1962).

6358 U.S. 450 (1959) (together with Williams v. Stockham Valves \& Fittings, Inc.). The Northwestern decision and its aftermath stimulated a great outpouring of legal commentary on many of the current problems in the field of state taxation of interstate commerce. The most extensive single treatment of both the present condition of the system of state taxation of interstate commerce and an analysis of the problems involved therein is the four volume report of the Special Subcommittee on State Taxation of Interstate Commerce, H.R. REP. No. 1480, 88th Cong., 2d Sess. (1964), H.R. REP. Nos. 565 and 952, 89th Cong. 1st Sess. (1965) [paginated 1-1255, and hereinafter cited as "REPORT"]. In addition, $A$ Symposium on State Taxation of Interstate Commerce, 46 VA. L. REv. 1051 (1960), Developments, 75 HARV. L. REv. 953 (1962), and Hartman, State Taxation of Corporate Income From a Multi-State Business, 13 VAND. L. REv. 21 (1959), survey many of the contemporary issues in the field.

7340 U.S. 602 (1951). In Northwestern the Court said: "Moreover, it is beyond dispute that a State may not lay a tax on the "privilege' of engaging in interstate commerce," citing Spector. 358 U.S. at 458.

8340 U.S. at 609.

9 The Connecticut statute provided in part: “... and every other corporation ... shall pay, annually, a tax or excise upon its franchise for the privilege of carrying on or doing business within the state, such tax to be measured by the entire net income as herein defined. . . " ConN. GeN. Stat. § 418(c) (Supp. 1939). 
identical to the measure of the tax given constitutional approval in Northwestern, ${ }^{10}$ it was apparent that exclusively interstate commerce could be taxed if the drafters of a state statute called the tax by the right name. ${ }^{11}$

The business community reacted sharply to Northwestern and subsequent judicial developments which seemed to broaden the states' power to tax interstate commerce. ${ }^{12}$ It feared that the states would utilize the constitutionally approved avenue of direct income taxation to tax businesses which, up to that time, were free of the levies. ${ }^{13}$ Responding to the pleas of business spokesmen, Congress acted with uncommon haste by enacting, just seven months after the Northwestern decision, a bill limiting the scope of the states' power to impose taxes levied on or measured by net income on interstate businesses. ${ }^{14}$ Since the bill was

10 The Minnesota statute provided in part: "An annual tax for each taxable year, computed in the manner and at the rates hereinafter provided, is hereby imposed upon the taxable net income for such year . . ." MiNN. STAT. \$290.03 (1945).

11 See Hartman, State Taxation of Corporate Income From a Multi-State Business, 13 VAND. L. REv. 21, 37 (1959). The Supreme Court's imposition of greater restrictions upon a state's taxing power over interstate commerce when the tax was denominated a privilege tax, rather than a direct net income tax, was justified in Spector by the following language: "Even though the financial burden on interstate commerce might be the same, the question whether a state may validly make interstate commerce pay its way depends first of all upon the constitutional channel through which it attempts to do so." 340 U.S. at 608 .

12 REPORT 7; Hartman, State Taxation of Interstate Commerce: A Survey and an Appraisal, 46 VA. L. REv. 1051 (1960). Several decisions followed in the wake of Northwestern either upholding the states' right to impose a direct net income tax on exclusively interstate commerce or refusing to consider taxpayers' complaints over such a tax: ET \& WNC Transp. Co. v. Currie, 248 N.C. 560, 104 S.E.2d 403 (1958), aff'd per curiam, 359 U.S. 28 (1959); International Shoe Co. v. Fontenot, 236 La. 279, 107 So. $2 d 640$ (1958), cert. denied, 359 U.S. 984 (1959); Brown-Forman Distillers Corp. v. Collector of Revenue, 234 La. 651, 101 So. $2 \mathrm{~d} 70$ (1958), appeal dismissed and cert. denied, 359 U.S. 28 (1959).

13 This fear was particularly strong among small and medium sized corporations which anticipated an increase in the number of diverse, conflicting, and overlapping state income tax laws. H.R. REP. No. 2013, 89th Cong., 2d Sess. 2 (1966). And it was probably compounded by the uncertainty of what the Supreme Court would do next, since the "tangled underbrush of past cases," as Justice Clark pointed out in Northwestern, "leaves much room for controversy and confusion and little in the way of precise guides to the States in the exercise of their indispensable power of taxation. This Court alone has handed down some three hundred full-dress opinions spread through slightly more than that number of our reports." 358 U.S. at 457-8 (1959).

14 P.L. $86-272$, 15 U.S.C. $\$ 381$ (1964). The statute is directed at defining the minimum intrastate activities required of an interstate corporation before liability for a tax of the kind sustained in Northwestern obtains. In particular the statute precludes a state from imposing an income tax upon a business where the only activity within the state is soliciting orders or using an independent contractor to make sales within the State.

P.L. 86-272 is the first and presently the only federal legislation limiting state taxation of interstate commerce. The constitutionality of the Act has been challenged in three cases: International Shoe Co. v. Cocreham, 246 La. 244, 154 So. 2d 314, cert. denied, 379 U.S. 902 (1964); Giba Pharmaceutical Products, Inc. v. State Tax Comm'n, 382 S.W.2d 645 (Mo. I964), and Smith, Kline \& French Laboratories v. State Tax Comm'n, 241 Ore. 50, 403 P.2d 
admittedly a stopgap measure, ${ }^{15}$ Congress at the same time established a special subcommittee to consider broadly the problems of state taxation of interstate commerce, and to propose remedial legislation. ${ }^{16}$

375 (1965). Smith, Kline of French is typical of all three. In approving the act and reversing the Oregon Tax Court, which had found the act unconstitutional, 5 State Tax Cas. If 250-116 (Ore. April 24, 1964), the Oregon Supreme Court held: "A state can levy an income tax upon revenues derived from interstate commerce. This is not because such tax is in a different area than [sic] congressional power 'to regulate commerce;' it is because, in the absence of congressional action to the contrary, both the state and federal legislature can legislate in this area. In the absence of congressional action to the contrary, the only restriction upon the states is judicially imposed,--state action must not unduly burden interstate commerce. Congress now has acted; its statute is contrary to the state action; the federal statute is valid and the state statute must yield." 241 Ore. at $60-61$, 403 P.2d at 380 .

Despite official statements by the Court that denial of certiorari has no meaning, the failure of the Court to accept the question of the act's constitutionality by denying certiorari to International Shoe has been commented on as implying either satisfaction with the finding of constitutionality in the state court, inability to deal with a poorly defined subject, or a desire for further development by state courts. Barnes, State Taxation of Interstate Commerce: Chaos and New Hope, I6 WesT. REs. L. REv. 859, 877 (1965). No support is available for any one position more than another, but the present status of federal control of state taxation of interstate commerce is decidedly in favor of constitutionality premised on the commerce clause as in Smith, Kline, \& French. In the REPORT, at 147 , the Subcommittee found a favorable constitutional outlook for such legislation, but not without reservation.

For further discussion of the constitutional problems presented by P.L. 86-272 see, e.g., Hellerstein, The Power of Congress to Restrict State Taxation of Interstate Commerce, 12 J. TAx. 302 (1960); Roland, Public Law 86-272: Regulation or Raid?, 46 VA. L. REv. 1172 (1960).

15 89th Cong., 2d Sess., House Comm. on the Judiciary, Special Subcomm. on State Taxation of Interstate Commerce, Hearings on H.R. 11798 at 7 (1966) [hereinafter cited as Hearings].

18 The scope of the Subcommittee's study, which initially embraced only state income taxation, was broadened by P.L. 87-17, 15 U.S.C. § 381, to include taxes on capital stock, sales, use, and gross receipts. The occasion for the broadening of the study was the Supreme Court's decision in Scripto, Inc. v. Carson, 362 U.S. 207 (1960), in which the Court held that Florida may require an out-of-state retailer soliciting sales in the state through independent wholesalers and jobbers to collect the state use tax. REPORT 9; cf. National Bellas Hess, Inc. v. Dep't of Revenue of Illinois, 386 U.S. 753 (1967).

This comment will be concerned primarily with taxes measured by income (generically termed income taxes) regardless of their nominal subject and with taxes measured by capital stock (generically termed capital stock taxes) and usually imposed on the privilege of doing business (in one form or another) in a state. Since capital stock taxes pose many of the same basic legal problems as do state income taxes, they may usefully be considered with income taxes, particularly with respect to the proposed congressional solution to interstate tax problems which considers them together. H.R. 2158, 90th Cong., 2d Sess., Tit. I, \$ 101(1), Tit. II, § 201 (1965). See part III infra.

There are three important similarities between the capital stock and income tax as applied to interstate commerce. First, every state which permits division of the tax base among the states apportions the base by a formula, whether net income or capital stock is to be divided. In either case, the corporation is considered as a totality, with the base that is associated with that totality prorated among the states. The measure of the tax (income or capital stock) is not based on some localized aspect of the corporation, such as 
After five years of labor, the congressional subcommittee produced the most extensive study of virtually all the major aspects of state taxation of interstate businesses in our history. ${ }^{17}$ But conflicting views as to the direction that further congressional legislation should take, and political opposition by the states to all further federal intervention, ${ }^{18}$ have thus far blocked congressional action, although a bill did pass the House in May, 1968.19 Moreover, the congressional activity provoked a counterreaction among the states, which turned their attention to the voluntary adoption of uniform legislation, ${ }^{20}$ in order to obviate what they feared would be further congressional inroads upon their taxing powers.

The recent decision of the New Jersey Supreme Court in Roadway Express, Inc. v. Director, Division of Taxation ${ }^{21}$ makes even further inroads into the tax-immune status of exclusively interstate business activity by undermining the distinction between a privilege tax measured by net income and a direct net income tax. In sustaining the imposition of New Jersey's privilege tax upon a corporation conducting exclusively interstate business in the state, the New Jersey court not

the property it owns or the transactions in which it engages, even though the subject may be. See REPORT 987-8. Second, similar compliance problems are presented by both taxes both in terms of determining whether any tax liability exists and in calculating the liability when it does exist. REPORT 988. Third, some states have already achieved a degree of internal uniformity between the two taxes through the use of common jurisdictional rules and apportionment formulas. $I d$.

The chief distinction in the law of the two taxes is that capital stock taxes must be apportioned for foreign corporations, Cudahy Packing Co. v. Hinkle, 278 U.S. 460 (1929), but not for domestic corporations, Kansas City, M. \& B.R.R. v. Stiles, 242 U.S. 111 (1916), while apportionment is required on all impositions of a net income tax.

Sales, use, and gross receipts taxes present problems, many of which are distinct from those involved in income and capital stock taxes. REPORT 1121-1128.

17 Volumes I and II were dated June 15, 1964; Volume III was dated June 30, 1965; and Volume IV was dated September 2, 1965.

18 Examples of state opposition are found in the Hearings at: 267 et seq. (Nevada), 284 et seq. (Oregon), 450 et seq. (North Carolina), 505 et seq. (Utah), 539 et seq. (Michigan), 548 et seq. (New Mexico), 644 et seq. (South Carolina), 834 et seq. (Georgia), 919 et seq. (Colorado), 1003 et seq. (Nebraska), 1026 et seq. (Texas), 1219 et seq. (Kansas), 1248 et seq. (Arizona), 1294 et seq. (Alabara), 1353 et seq. (Maryland), 1516 et seq. (California), 1617 et seq. (Wyoming), 1684 et seq. (Council of State Governments).

19 H.R. 2158 was approved by the House of Representative on May 22, 1968, as the "Interstate Taxation Act." The original bill, H.R. 11798, 89th Cong., 1st Sess. (1965), was never reported out of committee. It was then substantially amended and successfully reported out of committee as H.R. 16491, 89th Cong. 2d Sess. (1966), but it died at the end of the 89th Congress. H.R. 16491 was then re-introduced verbatim in the 90th Congress, 1st Session as H.R. 2158.

20 The Multi-State Tax Compact and the Uniform Division of Income for Tax Purposes Act represent the major counter-proposals of the states for voluntary state action rather than federally-imposed uniformity in state taxation of interstate commerce.

2150 N.J. 471, 236 A.2d 577 (1967), appeal dismissed, 390 U.S. 745 (1968). 
only suggests that the Supreme Court's decision in Spector no longer characterizes its attitude towards state taxation of interstate commerce, ${ }^{22}$ but it also furnishes an approach to the problem which would confine Spector's authority, as the opinion asserts, "at the very most, only [to] the precise statutory situation there found." 23

Judicial and legislative developments after Northwestern indicate that the power of the states to tax interstate commerce is being reconsidered and, apparently, redefined. The Roadway Express decision, as well as two other recent decisions adopting a similar approach to the problem, ${ }^{24}$ suggest a judicial method of broadening state taxing powers over interstate commerce by delimiting the privilege tax immunity afforded the exclusively interstate business. The legislative rumblings, on the other hand, foreshadow greater limitations on the states' taxing powers in uniform nexus ${ }^{25}$ and apportionment ${ }^{26}$ requirements for state taxation of interstate commerce.

This comment will examine the Roadway Express case, focusing on its approach to the constitutional limitations theoretically prohibiting a state from levying a privilege tax on a corporation conducting exclusively interstate business within the state. It will then examine the decision's implications for the tax statutes of other states. Finally, it will consider the proposed state and congressional reforms in the area of state apportionment of income and capital stock taxes on interstate businesses, in light of the broadening of state tax power over interstate commerce. It will emphasize the increasing judicial and legislative attention being devoted to the question of fairness in the taxation of interstate commerce.

22 Id. at 487,286 A.2d at 585 .

$23 \mathrm{Id}$.

24 General Motors Corp. v. Washington, 377 U.S. 436 (1964); Mid-Valley Pipeline Co. v. King, — Tenn. —, 431 S.W.2d 277 (1968).

25 Nexus refers to the due process requirement that a taxpayer have some relationship with a state in order to incur tax liability there. "[The] test is whether property was taken without due process of law, or if paraphrase we must, whether the taxing power exerted by the state bears fiscal relation to protection, opportunities, and benefits given by a state." Wisconsin v. J.C. Penney Co., 311 U.S. 435, 444 (1941). See generally Hellerstein, Allocation and Nexus in State Taxation of Interstate Businesses, 20 TAX L. REv. 259 (1965); Barnes, State Taxation of Interstate Commerce: Nexus and Apportionment, 48 MarQ. I. Rev. 218 (1964); Hirshberg \& Nedry, A Federal Concept of Doing Business, 46 VA. L. REv. 1241 (1960).

28 Apportionment refers to the division by the states of a multi-state corporation's tax base by means of a formula which uses such factors as payroll, property, and sales receipts to determine the percentage (for tax purposes) of a corporation's business carried on in a particular state. Two other methods of dividing a corporation's tax base are also used: specific allocation and separate accounting. For a discussion of the various methods of dividing income and their relative significance, see REPORT 157-249. 


\section{ROADWAY EXPRESS}

\section{A. The Issues in the Case}

The case dealt with the New Jersey corporation business tax ${ }^{27}$ as levied on Roadway Express, a Delaware corporation engaged in interstate motor freight trucking in the state. Roadway was not authorized to do business in New Jersey, but carried on substantial activities and owned property in the state. Roadway operated as a common carrier over a large portion of the country. Its New Jersey operations mainly consisted of carrying truckload lots of goods in its over-the-road vehicles to and from two terminals which it maintained in the state. Roadway made direct delivery or pickup in its fleet of city trucks to its New Jersey customers, unless a customer required a full truckload lot, in which case the over-the-road truck would go directly to or from the customer's place of business. In no case, however, did Roadway carry freight from one New Jersey location to another. The volume of these activities in New Jersey was substantial. In 1960, for example, Roadway's vehicles traveled over eleven million miles on New Jersey's highways, and $\$ 5,728,000$ out of total gross revenues of $\$ 71,380,000$ (about 8 per cent) was derived from its business in New Jersey. Roadway had built the larger of its two New Jersey terminals on land it owned at a total investment of nearly one million dollars; it employed 221 persons there. Roadway rented the smaller terminal, where it had only two employees. At its terminals, the corporation serviced and maintained its vehicles and solicited local business. It paid local property taxes, state motor vehicle registration fees on its local fleet, and state motor fuel and unemployment compensation taxes, among others. The tax assessed by the Director on its interstate operations amounted to $\$ 7,334.50$.

The basic provision of the New Jersey tax statute at issue reads:

Every domestic or foreign corporation which is not hereinafter exempted shall pay an annual franchise tax... for the privilege of having or exercising its corporate franchise in this State, or for the privilege of doing business, employing or owning capital or property, or maintaining an office, in this State. And such franchise tax shall be in lieu of all other State, county or local taxation upon or measured by intangible personal property used in business by corporations liable to taxation under this act. ${ }^{28}$

The measure of the tax is apportioned net worth plus apportioned net income. ${ }^{29}$

27 N.J. STAT. ANn. \& 54:10A-1 et seq. (1960).

28 N.J. STAT. ANN. \$ 54:10A-2 (1945).

29 New Jersey employs a three-factor (property, payroll, and receipts) formula in order 
Several issues frequently arising when a corporation seeks immunity from state taxation either were not contested or were disposed of with little difficulty in Roadway. No claim was made by Roadway that the tax was discriminatory, ${ }^{30}$ or that there was a risk of multiple taxation, ${ }^{31}$ or that there was unfair apportionment. ${ }^{32}$ Since the Director conceded that the levy was a privilege or franchise tax, there was no issue as to the subject of the tax before the court. And the court found, with a minimum of discussion, that despite the temporary interruptions in

to compute, in the case of an enterprise conducting multi-state activities, the amount of the income tax base properly attributable to New Jersey. N.J. STAT. ANN. $\$ 54: 10 A-5,-6$ (1960). The amount of the tax is determined by applying the specified rate to the apportioned base. The rate in the tax years in question here was a flat 13/4\%; this has been raised to $31 / 4 \%$ by [1966] N.J. Acts 134. As for net worth, the greater of either an assetsapportionment formula or the three-factor formula is used, and a low rate of two mills per dollar on the first $\$ 100,000,000$ is applied, subject to a minimum tax.

The three-factor formula (the so-called "Massachusetts type") takes an average of the following three fractions,

$$
\begin{aligned}
& \text { (1) In-State property } \\
& \text { Total property } \\
& \text { (2) In-State payroll } \\
& \text { Total payroll } \\
& \text { (3) In-State sales (receipts) } \\
& \text { Total sales (receipts) }
\end{aligned}
$$

however determined, multiplies it by the base (the income or capital stock to be divided among the taxing states), and then applies the rate. REPORT 168-9.

30 Discrimination against interstate commerce is unconstitutional if different burdens are imposed on in-state and out-of-state goods on the face of the taxing statute, Welton v. Missouri, 91 U.S. 275 (1875), or if the tax, though purporting to treat in-state and interstate commerce alike, in operation puts interstate commerce at a complitive disadvantage, Robbins v. Shelby County Taxing District, 120 U.S. 489 (1887) (one ground of holding). See generally P. Hartman, State Taxation of Interstate Commerce 67-70 (1953); J. Hellerstein, State and Local Taxation 219-20 (2d ed. 1961); Developments, 75 HARV. L. REv. 953, 962-4 (1962).

31 See International Harvester Co. v. Evatt, 329 U.S. 416 (1947); International Harvester Co. v. Dept. of Treasury, 322 U.S. 340 (1944); McGoldrick v. Berwind-White Coal Mining Co., 309 U.S. 33 (1940); Western Live Stock v. Bureau of Revenue, 303 U.S. 250 (1938). A tax imposed by a state which in no sense subjected interstate business to an unfair disadvantage against the state's local business might still be struck down if the risk of cumulative taxation from other states imposing a similar tax would subject the business in question to a tax burden not borne by local business. See generally J. HeLLERSTERN, State and Local Taxation 16l-3 (2d ed. 1961); P. Hartman, State TAxation of INTERstate Commerce 69 (1953); Developments, 75 Harv. L. Rev. 953, 964-5.

32 Both due process clause and commerce clause objections may be raised to challenge an allegedly improper apportionment scheme. The due process clause forbids extraterritorial taxation so that if an apportionment formula results in taxation of a larger portion of the applicable base than is properly attributable to a state, the Court will strike it down on due process grounds. Norfolk \& W. Ry. v. Missouri State Tax Comm'n, 390 U.S. 317 (1968); Fargo v. Hart, 193 U.S. 490 (1904). Although the issue under the commerce clause, given a constitutionally authorized subject of a tax, is whether an undue burden has been imposed on the commerce, the criteria under this clause for a valid apportionment formula appear to be fundamentally the same as those under the due process clause. Norfolk \& W. Ry. v. Missouri State Tax Comm'n, 390 U.S. 317, 325 n.5 (1968). 
Roadway's shipping operations in the state, "[a]ll the freight traffic with which the New Jersey terminals were concerned must be said to be interstate in character." 33 Consequently, the tax could not be upheld on the basis that Roadway did some intrastate business. ${ }^{34}$

The issue squarely facing the court, then, was whether a fairly allocated and nondiscriminatory franchise or privilege tax could constitutionally be imposed upon a foreign corporation doing exclusively interstate business in the state. Unless the court construed the tax solely as an "in lieu of" property tax on Roadway's intangibles in order to bring it within the principle of Railway Express Agency, Inc. v. Virginia ${ }^{35}$ a difficult task in the light of the court's unqualified characterization of the tax as a privilege levy-Spector would seem to have dictated the invalidation of the levy as an interference with the tax-immune privilege of doing interstate business.

\section{B. The Opinion}

A unanimous court, speaking through Judge Hall, upheld the levy. The decision was based on three independent propositions, each of which theoretically would have been sufficient for sustaining the tax: first, the privileges taxed by the New Jersey statute are distinguishable from the privilege of doing business, which was the subject of the tax in the Connecticut levy at issue in Spector; ${ }^{36}$ second, the minority

\footnotetext{
33 Roadway Express, Inc. v. Director, 50 N.J. at 479, 236 A.2d at 581 (1967).

34 See City of Chicago v. Willett Co., 344 U.S. 574 (1953); Norton Co. v. Dep't of
} Revenue of Ill., 340 U.S. 534 (1951).

35358 U.S. 434 (1959). In the first Railway Express case, Railway Express Agency, Inc. v. Virginia, 347 U.S. 359 (1954), the Supreme Court struck down a Virginia tax imposed on a taxpayer engaged in exclusively interstate business in Virginia, holding that it was a privilege tax within the meaning of Spector, and therefore could not be constitutionally applied to a business exclusively interstate. Virginia then amended its statute to read: "each express ... company ... shall ... pay to the State, a franchise tax which shall be in lieu of taxes upon all of its other intangible property and in lieu of property taxes on its rolling stock." VA. ConE $\S 58-546$ et seq. (1950), as amended by [1956] Va. Acts 612. The second Railway Express case, Railway Express, Inc. v. Virginia, 358 U.S. 434 (1959), which upheld the new levy as applied to an exclusively interstate business, said, in pertinent part: "The new tax is not denominated a license tax laid on the 'privilege of doing business in Virginia' . . . The General Assembly has made crystal-clear that the $\operatorname{tax}$ is ... 'in lieu of taxes upon all of its other intangible property. . . ' " Id. at 438.

The Court has sustained a number of gross receipts taxes levied on railroads, express companies, and other instrumentalities of interstate commerce on the basis that these taxes are not actually imposed directly on interstate commerce or on the tax-immune privilege of doing exclusively interstate business in a state, but that they are "in lieu of" property taxes which could legitimately be imposed on the enterprise in question. Illinois Cent. R.R. v. Minnesota, 309 U.S. 157 (1940); Postal Tel. Cable Co. v. Adams, 155 U.S. 688 (1895); Maine v. Grand Trunk Ry. Co., 142 U.S. 217 (1891). See generally J. HeLlERstein, State and Local Taxation 215-6 (2d. ed. 1961); P. Hartman, State Taxatron of INTERSTATE COMMERCE 183-7 (1953).

36 See note 9 supra. 
opinion in Spector represents the present posture of the Supreme Court towards state taxation of interstate business; third, the tax is a levy in lieu of other state taxes which could be validly imposed on exclusively interstate business. This comment will deal only with the first two aspects of the opinion. Although the "in lieu" feature of the tax may have been controlling in the Supreme Court's dismissal of Roadway's appeal for lack of a substantial federal question, ${ }^{37}$ the major significance of the decision lies in its direct attack on tax immunity derived from the privilege of doing interstate business.

Judge Hall's opinion distinguishes the incidence of the New Jersey privilege levy from the incidence of the privilege levy at issue in Spector. The opinion points to privileges taxed under the New Jersey statute which are not found in the Connecticut tax. While the Connecticut levy is a franchise tax imposed on the "privilege of carrying on or doing business within this state," 38 the New Jersey tax embraces not only the privilege of doing business, but also the privileges of exercising a corporate franchise, owning property, employing capital and maintaining an office. ${ }^{39}$ The court concludes that a "franchise tax may be imposed [upon an exclusively interstate business] if the incidence or basis is a privilege other than engaging in that business as such. ..."40 Since only the privilege of engaging in business "as such" was within the constitutional privilege announced in Spector, a state remains free to tax an exclusively interstate business as long as, in the precise language of the statute, the levy is not imposed solely on the privilege of doing business in the state.

Having found a semantic solution to the issue before the court, ${ }^{41}$ Judge Hall suggests a second and more fundamental basis for sustaining the New Jersey tax:

While a tax basis worded as is New Jersey's has never been passed upon by the nation's highest court, we earnestly believe that the current course of its opinions in the field, as we read them, points to the conclusion that this levy is valid as applied to exclusively interstate business. ${ }^{42}$

\footnotetext{
37390 U.S. 745 (1968).

38 Conn. Gen. Stat. § 418(c) (Supp. 1939).

39 N.J. Stat. ANN. § 54:10A-l et seq. (1945).

4050 N.J. at 489,236 A.2d at 586.

41 The triumph of form over substance is emphasized by Judge Hall's remark, referring to the New Jersey tax: "There seems to be no question that, if it had been enacted and denominated as a direct corporate income tax, it would have been validly applicable to the taxpayers here by virtue of Northwestern States Portland Cement Co. v. State of Minnesota ..." Id. at 485, 236 A.2d at 584 .

42 Id. at $485-6,236$ A.2d at $584-5$.
} 
Three post-Spector opinions of the Supreme Court support this proposition. Northwestern approved a state income tax levied on the income from an exclusively interstate business. ${ }^{43}$ The second Railway Express case approved a state "in lieu" tax on an exclusively interstate business. ${ }^{44}$ And the recent decision in General Motors Corp. $v$. State of Washington ${ }^{45}$ approved a state privilege tax on the gross receipts from interstate selling traditionally regarded as exclusively interstate commerce ${ }^{46}$ because there were sufficient "local incidents" to warrant the levy. ${ }^{47}$ Furthermore, there is additional support for Judge Hall's proposition in Memphis Natural Gas Co. $v$. Stone, ${ }^{48}$ decided three years before Spector, in which the Supreme Court approved a tax on the maintenance of property within the state by a corporation doing exclusively interstate commerce in the state. Taken together, these four decisions substantially narrow the tax immunity which had seemingly been accorded the privilege of engaging in exclusively interstate activity, ${ }^{49}$ emphasizing that "the founders did not intend to immunize such commerce from carrying its fair share of the costs of the state government in return for the benefits it derives from within the state."50 By chipping away at the protection Spector seemed to give interstate business, the Memphis Gas and General Motors cases in particular illustrate the tendency of the Court to fragment the privilege of doing business in sustaining a state tax on significant components of exclusively interstate activity.

In the Memphis Gas case, Mississippi had levied its franchise tax on the Memphis Natural Gas Company, a Delaware corporation which owned and operated a pipe line in the state, although not authorized to do business there. The corporation had only one customer in the taxing state; its only employees were those necessary to maintain the line; and it was stipulated that the company "has never engaged in any intrastate commerce in Mississippi."'52 In sustaining the levy over the

43 Northwestern States Portland Cement Co. v. Minnesota, 358 U.S. 450 (1959).

44 Railway Express Agency, Inc. v. Virginia, 358 U.S. 434 (1959). The decision was handed down on the same day as the Northwestern decision.

45377 U.S. 436.

46 See Memphis Steam Laundry Cleaners, Inc. v. Stone, 342 U.S. 389 (1952); Alpha Portland Cement Co. v. Massachussetts, 268 U.S. 203 (1925).

47377 U.S. at 447 (1964).

48335 U.S. 80 (1948).

49 See Memphis Steam Laundry Cleaners, Inc. v. Stone, 342 U.S. 389 (1952); Spector Motor Service, Inc. v. O'Connor, 340 U.S. 602 (1951); State Tax Comm'n of Mississippi v. Interstate Natural Gas Co., 284 U.S. 41 (1931); AIpha Portland Cement Co. v. Massachusetts, 268 U.S. 203 (1925).

50 Northwestern States Portland Cement Co. v. Minnesota, 358 U.S. 450, 461-2 (1959).

51 Miss. CODE, § 9314 (1942).

52 Memphis Natural Gas Co. v. Stone, 335 U.S. 80,81 (1948). 
taxpayer's objection that its imposition violated the commerce clause, the Court accepted the Mississippi Supreme Court's construction of the statute as

an exaction .... as a recompense for its protection of ... the local activities in maintaining, keeping in repair, and otherwise in manning the facilities of the system throughout the 135 miles of its line in this State, ${ }^{53}$

and dismissed as "idle" the suggestion that the tax was imposed on "the privilege of engaging in interstate business." ${ }^{44}$ According to the Court, the privilege did not prevent an activity admittedly essential to the conduct of an interstate business from being classified as a "local activity" for purposes of state taxation..$^{55}$

The Court in General Motors, as in Memphis Gas, by isolating various facets of interstate activity, sustained a Washington privilege tax measured by gross receipts from interstate sales. ${ }^{.8}$ General Motors, a Delaware corporation, manufactured vehicles and parts outside Washington which it sold to retail dealers in the state. It maintained a small branch office and warehouses in the state, employed forty in-state personnel, and sent its out-of-state personnel into the state from time to time. While reaffirming that "a state may not lay a tax on the 'privilege' of engaging in interstate commerce," ${ }^{57}$ the Court said that Washington was merely trying to tax "other activities or aspects of this [interstate] business which, unlike the privilege of doing interstate business, are subject to the sovereign power of the state." ${ }^{8}$ Whatever the privilege of engaging in interstate business may be, these "local incidents" were apparently not within its ambit since they were "sufficient to form the basis for a levy of a tax that would not run contrary to the Constitution."

Roadway Express is a logical extension of the reasoning of both Memphis Gas and General Motors. The New Jersey court, using a technique parallel to that of the Supreme Court, spelled out certain activities which it did not consider within the privilege of doing business, namely, the exercise of a corporate franchise, the ownership of property, the employment of capital, and the maintenance of an office within a state. Similar reasoning has been used in other state decisions.

63 Stone v. Memphis Natural Gas. Co., 201 Miss. 670, 674, 29 So. 2d 268, 270 (1947).

54 Memphis Natural Gas Co. v. Stone, 335 U.S. 80, 85 (1948).

55 Id. at 87.

66 General Motors Corp. v. Washington, 377 U.S. 436 (1964).

67 Id. at 446.

$68 I d$. at 447. Insert is found in the original text.

69 Id. at 448 . 
The Tennessee Supreme Court, for example, neatly avoided the impact of the Spector case on its corporate franchise tax by holding that, despite the Supreme Court's proscription in Spector of a levy on the right to do interstate business, " $[\mathrm{t}]$ he right to do business in corporate form was not involved in the [Spector] case." 60 A recent decision handed down by the Ohio Board of Tax Appeals (in a case whose facts are almost identical to those of Roadway Express) sustained Ohio's franchise tax on an exclusively interstate business, holding that since, in addition to the doing of business in the state, "the tax is based disjunctively on 'owning or using a part or all of its capital or property in this state," "61 it was therefore not a tax on the privilege of doing business within the meaning of Spector.

\section{The State Statutes}

Judge Hall's opinion in Roadway Express, if followed by other state courts, could have wide repercussions in extending state taxation of interstate business. In state after state, the standard tax services, relying on Spector, indicate that any corporation doing an entirely interstate business will not be subject to state franchise or privilege taxes. ${ }^{62}$ The following brief survey and analysis of the state tax statutes suggest the implications that Roadway Express might have concerning this supposed immunity.

A significant number of states are affected by the Roadway Express analysis. Of the forty states ${ }^{63}$ which have taxes measured by corporate income, thirty-four have direct income taxes in which income is both the subject and the measure of the tax. ${ }^{64}$ These thiry-four states may

60 Texas Gas Transmission Corp. v. Atkins, 197 Tenn. 123, 129, 270 S.W.2d 384, 387, cert. denied, 348 U.S. 883 (1954). See Mid-Valley Pipeline Co. v. King, ᄂ Tenn. —, 431 S.W.2d 277 (1968).

61 Cooper-Jarrett, Inc. v. Porterfield (B.T.A. No. 64747, 10-3-67), P-H State and Local Taxes, Ohio ๆ 17,008 .

62 See, e.g., P-H State and Local Taxes, 1 All States Unit If 92,222.

63 Although the Distict of Columbia imposes a tax on the privilege of doing business in or receiving sources of income from the District, D.C. CoDE \$ 47-1580 (West, 1968), it will not be considered here since the commerce clause restrictions applicable to the states are not similarly applicable to Congress in legislating for the District. Neild v. District of Columbia, 110 F.2d 246 (1940). Hence, Spector would not limit the District of Columbia's power to tax exclusively interstate business activity.

64 ALA. Cone tit. 51, § 398 (1958); ALASKa STAt. \$ 43.20.010(b) (1962); ArIz. Rev. Stat. ANN. § 43-102 (1956); ARK. STAT. ANN. § 84-2004 (1960); CALIF. REv. \& TAX. Code \$§ 23151, 23501 (Supp. 1967); Colo. Rev. Stat. ANN. \$ 138-1-3 (1963); Del. Code ANN. tit. 30, § 1902 (Supp. 1966); Ga. Code ANN. \$ 92-3102 (Supp. 1967); HAwaII REv. LAws §§ 121-23(a) (Supp. 1965); Idaho Code ANN. §§ 63-3025, 3025A (Supp. 1967); IND. ANN. Stat. \$ 64-3219 (Supp. 1967); Kan. Gen. Stat. ANN. § 79-3203(b) (Supp. 1965); Ky. Rev. Stat. ANN. § 141.040 (1963); LA. Rev. Stat. ANN. § 47:31 (Supp. 1952); MD. ANN. Code art. 81 § 288(b) (Supp. 
constitutionally impose their levies upon an exclusively interstate business under the principle of Northwestern. The five states (and New Jersey) using income as a measure only, impose their levies upon the privilege of doing business or of carrying on certain specified activities within the state. ${ }^{65}$ These five states are of interest here since their provisions are comparable to those of New Jersey.

A privilege tax measured by the value of a corporation's capital stock $^{66}$ is levied by thiry-seven states. Since seven states impose this tax only on domestic corporations, ${ }^{67}$ and eight states impose it only on domestic corporations and foreign corporations which have formally been authorized to do business in the state, ${ }^{68}$ it is only the other twentytwo states which in theory, at least, impose their capital stock tax on all interstate corporations, and which are the concern of this comment. ${ }^{69}$

1967); Mass. ANN. Laws ch. 63, $\$ 39$ (Supp. 1967); Mich. Stat. ANN. \& 7557 (132) (Supp. 1968); Minn. Stat. ANN. $\$ \S 290.02,290.03$ (1962); Miss. Code ANN. § 9220-03(2) (Supp. 1966); Mo. AnN. Stat. § 143.040.1 (1952); NeB. Session Laws, 1967, ch. 487, § 34(1); N.M. Stat. ANN. § 72-15A-6 (Supp. 1967); N.C. Gen. Stat. § 105-180-3 (Supp. 1967); N.D. Cent. Code $\$ \S 57-38-11,57-38-30$ (Supp. 1967); ORLA. STAT. ANN. tit. 68, § 2304 (1966); ORE. REv. StAT. §§ 317.070(I), 318.020 (Supp. 1965); PA. Stat. ANN. tit. 72, §§ 3420c, 3420n-3 (Supp. 1967); R.I. GEN. LAWS ANN. \& 44-11-2 (Supp. 1967); S.C. Code ANN. § 65-222 (1962); UTAF CODE ANN. §§ 59-13-3, 59-13-65 (Supp. 1967); VT. STAT. ANN. tit. 32, \& 5832 (Supp. 1968); VA. CODE ANN. § 58-128 (Supp. 1968); W. VA. Code ANN. § 11-24-4 (Supp. 1968); Wis. StaT. ANN. § 71.01(1) (Supp. 1968).

Seven of these thirty-four state statutes are of the so-called "double-barrel" type, in that the state supplements its franchise tax measured by net income with a direct net income tax. Liability for the income tax obtains only to the extent that the franchise tax is inapplicable as it is in the case of an enterprise conducting exclusively interstate business in the state. In this situation, the income tax, under the principle of Northwestern, could be validly levied on the corporation. The states with this kind of "double-barrelled" levy are: California, Idaho, Massachussetts, Minnesota, Oregon, Pennsylvania, and Utah.

65 Conn. Gen. Stat. ANn. § 12-214 (Supp. 1968); Iowa Code ANn. \$ 422.33 (1968); N.J. SтAT. ANN. §§ 54:10A-2, 54:10A-5 (1960, Supp. 1967); N.Y. TAX LAW \$ 209 (1966); TENN. Code ANN. \& 67-2701 (Supp. 1968).

Montana imposes an excise tax in the form of a "license fee" for carrying on business within the state, but it is essentially a privilege tax measured by net income. MoNr. Rzv. CODE ANN. \$ 84-1501 (Supp. 1967).

ob Such a tax must be apportioned to the taxing state in the case of a foreign corporation. See supra note 16.

67 Det. Code ANN. tit. $8 \S \S 501,503$ (1966); ME. Rev. Stat. ANN. tit. 36, § 2401 (1964); MD. ANn. Code art. 81, § 197 (1957); N.H. Rev. Stat. ANn. § 294:117 (1955); OrE. REv. Stat. § 57.767(1) (1965); R.T. GEN. LAWS ANN. § 44-12-1 (1956); VA. CODE ANN. § 58-456 (1950). 68 ARK. Stat. ANN. \& 84-1833 (1947); Colo. REv. Stat. § 31-10-7 (1963); IDAHo CodE $\S \S 30-602,30-603$ (1967); ILL. REv. STAT. ch. 32 §§ 157.131, 157.138 (Supp. 1967); Iowa CodE $\S \S 496 A .126,496 A .127$ (Supp. 1968); S.C. CoDE $\$ \S 65-602$, 65-606 (Supp. 1967); WYo. STAT. ANN. \& 17.46 (1957).

Washington imposes its capital stock tax only on those foreign corporations doing or seeking to do intrastate business in the state. The levy may therefore be considered in the same category as the levies noted immediately above since there is no attempt to tax the exclusively interstate business.

69 ALA. Code tit. 51, §§ 347, 348 (Supp. 1967); ConN. Gen. Stat. ANN. §§ 12-214. 12-219 
Although the capital stock tax (whether denominated a privilege or a direct net income tax) is not as important a source of state revenue as the corporate income tax, ${ }^{70}$ the legal problems involved in the imposition of these excise taxes on an exclusively interstate business are the same. Therefore, no distinction will be made between an income and a capital stock measure in considering the implications of Roadway Express upon the twenty-seven state statutes in question. ${ }^{71}$

The Privilege of Having or Exercising Its Corporate Franchise in This State: Louisiana, ${ }^{72}$ New York, ${ }^{73}$ Tennessee. ${ }^{74}$ Roadway Express is au-

(1958); Fla. Stat. § 608.33(1) (Supp. 1968); GA. Code ANn. § 92-2401 (Supp. 1967); Kan. GEN. StAT. ANN. § 17-702 (1963); KY. REv. StAT. ANN. \$§ 136.070, 136.072 (1963); LA. REv. STAT. § 47:601 (1955); Mass. GeN. Laws ch. 63, § 39 (Supp. 1967); Mich. STat. ANN. § 21.205 (Supp. 1968); Mrss. Code ANN. §§ 37-9314, $37-9317$ (Supp. 1966); Mo. REv. Stat. § 10.147 .010 (Supp. 1967); Neb. Rev. Stat. \$§ 21-303, $21-306$ (1962); N.J. Rev. StaT. § 54:10A-5 (Supp. 1967); N.Y. TAX LAW §§ 209.1, 210 (1966); N.C. GEN. STAT. \$§ 105-114, 105-122(b) (Supp. 1967); OHIo Rev. Code \$§ 5733.01, 5733.05 (1967); OKLA. Stat. ANN. tit. 68, § 1201, 1209 (1965); PA. Stat. ANN. tit. 72, §§ 1871(b), 1901 (Supp. 1967); Tenn. Code ANN. \$§ 67-2902, 67-2904 (Supp. 1968); Tex. Crv. Stat. tit. 122A, art. 12.01(1) (Supp. 1967); W. VA. Code § 11-12-80.

70 REPORT 909.

71 The procedure employed in categorizing the statutes was as follows: every alternative basis for the imposition of the tax was considered independently; if a statute fit into more than one category it would be placed in both of them with this exception: if one of the categories was specifically the privilege of doing business, the other category or categories only would be considered since they would necessarily be less restrictive. When the language of the New Jersey statute did not adequately describe a category, the language of the first state listed has been used.

72 LA. REv. STAT. \& 47:601 (1955).

73 N.Y. TAX LAW $\$ \S 209,210$ (1966).

74 Tenn. Code ANn. $\$ \S 67-2701,-2902,-2904,-2908$ (Supp. 1968). Tennessee's attempts to tax exclusively interstate business have had a particularly interesting and relevant history. Because the Tennessee State Constitution forbids a general direct tax on net income [TEnn. Const. art. II, § 28], Tennessee has had a privilege tax measured by net income. Before section 67-2701 was amended in 1955, it was held that the tax was on the privilege of doing business in corporate form, distinguishable from the Connecticut statute in Spector, and consequently applicable to a foreign corporation doing business in Tennessee, even though engaged in exclusively interstate commerce there. Texas Gas Transmission Corp. v. Atkins, 197 Tenn. 123, 270 S.W.2d 384, cert. denied, 348 U.S. 883 (1954). However, in the Texas Gas case, the corporation had qualified to do business in Tennessee, so that it was still unclear whether an unqualified corporation doing exclusively interstate business would be subject to the levy. In 1955, the Tennessee Legislature amended the statute and made it clear that whether a business actually qualified or not made no difference since the tax was a "recompense for the protection of its local activities and as compensation for the benefits it receives from doing business in Tennessee." TENN. CODE ANN. \$ 67-2701 (Supp. 1968). Since the tax was still on the privilege of doing business, however, it remained unclear whether an exclusively interstate corporation not qualified to do business in the state was taxable. REPORT 346.

In August 1968, the Tennessee Supreme Court upheld the state's privilege tax on a corporation doing exclusively interstate business in the state, taking an approach almost identical to the New Jersey Court's opinion in Roadway Express, from which it quoted extensively. Mid-Valley Pipeline Co. v. King, — Tenn. —, 431 S.W.2d 277 (1968). The 
thority for the proposition that a tax may be imposed on the exercise of a corporate franchise, even though the corporation exercising that franchise is doing exclusively interstate business. ${ }^{75}$ By pointing to this phrase in the New Jersey statute as one of the alternative bases of the tax, Judge Hall was in effect making the point that the privilege of doing business is distinguishable from the privilege of doing business in the corporate form. Doing business in the corporate form is only one of the many ways in which one may engage in interstate business. To tax only one particular form of engaging in interstate business is no more to tax the entire privilege than is the taxation of the local incidents of interstate business a tax upon the entire privilege. ${ }^{78}$

The Privilege of Owning Capital or Property in This State: Florida, ${ }^{77}$ Kentucky, ${ }^{78}$ Louisiana, ${ }^{70}$ Michigan, ${ }^{80}$ Ohio, ${ }^{81}$ Pennsylvania, ${ }^{82}$ Texas. ${ }^{83}$ According to Roadway Express, the privilege of owning property or employing capital in a state may likewise be distinguished from the privilege of carrying on interstate business. ${ }^{84} \mathrm{~A}$ foreign manufacturing corporation, for example, may send salesmen into a state and solicit a substantial volume of business there without the aid of any local capital or property. In specifying certain activities, such as the ownership or use of local property, the state legislature may be consciously attempting to single out for taxation those local activities which, though an essential

plaintiff was a foreign corporation engaged in transporting crude oil from points in Texas, Louisiana, and Arkansas to points in Kentucky and Ohio by a pipeline passing through Tennessee. It had not qualified to do business in Tennessee and employed only four people there-two pumping station foremen and two communication technicians. Although the taxpayer's business was solely interstate, the court held that the taxpayer was engaged in sufficient local activities-maintenance of pumping stations and microwave towers by employees residing in Tennessee, and contracting for service and acquiring title to property in its corporate name-to provide a basis for the imposition of the franchise and excise taxes. Such local activities, although incidental to the conduct of interstate commerce were held to be taxable on the basis of the reasoning in the Memphis Gas and Roadway Express decisions. The court said in part:

The fact complainant is and has been solely engaged in interstate commerce within this State is not determinative ... [T] he privileges taxed in Spector under the Connecticut statute were confined to those of "carrying on or doing business within the state ...' [T] he taxes are imposed upon the privilege of doing business in corporate form and are nondiscriminatory as they apply to all foreign corporations doing business in this State in corporate form.

Id. at - 481 S.W.2d at 280, 283 (1968).

7550 N.J. at $491-2,236$ A.2d at 588.

76 General Motors Corp. v. Washington, 377 U.S. 496, 447 (1964).

77 FlA. Stat. § 608.33(1) (Supp. 1968).

78 KY. REV. STAT. $\S \S 136.070,136.072$ (1963).

79 LA. REV. STAT. \& 47:601 (1963).

$80 \mathrm{Mich}$. Stat. ANN. $\$ 21.205$ (Supp. 1968).

81 OHIo REv. CoDE $\S \S 5733.01,5733.05$ (1967).

82 Pa. Stat. ANN. tit. 72, §§ 1871(b), 1901 (Supp. 1967).

83 Tex. Crv. Stat. tit. 122A, art. 12.01(1) (Supp. 1967).

8450 N.J. at 492,236 A.2d at 588. 
part of interstate commerce, are nevertheless "apart from the flow of commerce,"85 to use the language of the Memphis Gas case, and therefore not protected by the tax immunity granted to the privilege of doing interstate business.

Having One or More Individuals Receiving Compensation in This State: Kentucky, ${ }^{86}$ Michigan. ${ }^{87}$ It is certainly possible to conceive of conducting an interstate business in a state without employing personnel there. For example, interstate trucking companies may conduct operations in a state without any locally employed personnel. It is only when a business enterprise is personally represented in a state, with its personnel enjoying the protection of its police and public facilities, that the state imposes a tax. The reasoning in Roadway Express would suggest that this is not a tax on the privilege of doing business but rather a levy on a distinct privilege of a particularly local character and therefore taxable, though part of interstate activity.

Similar analyses of the remaining state statutes yield similar results. ${ }^{88}$

\section{B. Evaluation of the Roadway Express Approach}

Although, as the above analysis seems to demonstrate, it may be possible to distinguish many existing state statutes from the statute at issue in Spector through semantic exercises, the result would be to turn the privilege of doing business into an abstraction without substance.

\footnotetext{
85 Memphis Natural Gas Co. v. Stone, 335 U.S. 80, 96 (1948).

86 KY. REv. STAT, §§ 136.070, 136.072 (1963).

87 Mrat. Stat. ANN. \$ 21.205 (Supp. 1968).

88 Some of the other more common statutory provisions are "doing business in the state," AlA. CoDE tit. 51, §§ 347, 348 (Supp. 1967), FLA. Star. § 608.33(1) (Supp. 1968), IowA CODE ANN. \$ 422.33 (1949), LA. REv. Star. § 47:601 (1955), Mo. REv. Stat. § 10.010, 10.147 (Supp. 1966), N.M. Stat. ANN. § 51-13-2 (Supp. 1967), N.G. GEN. STAT. §§ 105-114, 105-122(b) (Supp. 1967), TENN. CoDE ANN. §§ 67-2701, 67-2902, 67-2904 (Supp. 1968); "recompense for the benefit and protection afforded by the government and laws of the state for the activities carried on within the state," ConN. GEN. STAT. ANN. \$§ 12-214, 12-219 (1958), TENN. CODE ANN. $\$ \S 67-2701$ (Supp. 1968); "the privilege of carrying on its business within this state," Ga. Code ANn. § 92-2401 (Supp. 1967), Mont. Rev. Code ANN. § 84-1501 (Supp. 1958).

Although these provisions are in many ways much closer or nearly identical to those at issue in Spector, it is possible to distinguish each state statute from that of Connecticut. The language of "recompense" in the Tennessee and Connecticut (revised after Spector) statutes, for example, points to certain activities which receive the benefit of state laws and government, even though these activities may be part of the exclusively interstate business carried on in the state. And while it may appear untenable at first blush to try to draw a distinction between a tax on doing business and a tax on the privilege of doing business, there is nevertheless an argument to be made if one carries Judge Hall's reasoning in Roadway Express to its logical extreme: If the question of constitutionality of a tax on interstate commerce depends on whether the statute imposes a levy on the privilege of doing business as such, a tax on the doing of business may be construed by a court to embrace those activities, such as the maintenance of local property, which are distinct from the privilege of engaging in interstate business as such, and are therefore taxable.
} 
In effect, the battle over the meaning and extent of the constitutionally protected privilege of doing business in a state is being fought on conceptual quicksand. The cases, ${ }^{89}$ by seizing on one "taxable" aspect of the privilege, such as the maintenance of local property or the exercise of a corporate franchise, actually destroy the entire concept. While there is a theoretical distinction between the privilege of doing business and the privilege of doing business in corporate form, it is a distinction which emasculates the commerce clause protection afforded interstate business which is by and large carried on by corporations..$^{90}$ While it may be possible to carry on an interstate business without owning property or employing capital in a state, to limit the protection of the commerce clause to those that do not is to limit its protection to only a small minority of businesses. And while there may be a verbal distinction between the tax-immune privilege of doing business and its taxable local incidents, it is questionable whether the Supreme Court will reverse any state court finding that there are sufficient local incidents to justify the distinction and, consequently, the imposition of its privilege tax. If the privilege of doing interstate business has any meaning, its protection certainly cannot be limited to the unincorporated association owning no property in a state where it has no employees.

Roadway Express represents a rejection of the privilege concept as a constitutional standard in controversies involving state taxation of interstate commerce. Either it is saying that the privilege of doing interstate business considered as a whole cannot be taxed, but that its component parts, such as the ownership of property or the exercise of a corporate franchise, can be taxed; or it is saying that the privilege of doing business cannot be taxed, but that the activities that constitute the normal conduct of interstate business, such as employing capital in a state and doing business in the corporate form, are not part of that privilege. Such reasoning erodes the privilege and implies that the decisions of the Supreme Court in this field spring from considerations which the language of its opinions tends only to obscure.

The fundamental policy issue underlying these developments is whether there remains any justification for continuing to grant the abstract privilege of carrying on interstate business whatever tax immunity it still enjoys. Three considerations in particular suggest that

89 General Motors Corp. v. Washington, 377 U.S. 436 (1964); Memphis Natural Gas Co. v. Stone, 335 U.S. 80 (1948); Roadway Express, Inc. v. Director, 50 N.J. 471, 236 A.2d 577 (1967); Mid-Valley Pipe Line Co. v. King, - Tenn. -, 431 S.W.2d 277 (1968).

90 The Report indicated: "When the total of all manufacturing and mercantile activity is taken into account, it is found that while corporations comprised only 17 percent of about 3 million business units, they reported 82 percent of all business receipts and 75 percent of all net income originating in these industries." REPORT 17. 
there does not. First, since the Supreme Court approved the imposition of a state's net income tax on an exclusively interstate business in Northwestern, there is no longer any economic justification for the perpetuation of the tax immunity granted the privilege of doing an interstate business, when the tax is measured by net income.91 Second, the narrow privilege immunity expands and contracts according to semantic variations in state statutes and the ingenuity of state courts. Third, barring any problem of discrimination, multiple burdens, or insufficient nexus, there is no reason why a state should not be permitted to collect revenue from every business which enjoys the benefits and protection which the state affords those enterprises owning local property, employing local personnel, or exploiting the local market.92 Furthermore, as long as interstate corporations are not subjected to a tax on more than one hundred per cent of their tax base as a result of inconsistent state apportionment formulas and as long as the corporation in question has a sufficient connection with the taxing state to justify tax liability, to continue to provide interstate businesses with tax immunity would tend to put the taxable local business at a competitive disadvantage..$^{93}$

Taxation of the privilege of doing interstate business would be only the first step in moving towards a more rational reconciliation of conflicting interests: that of the states in obtaining sorely needed revenue from interstate business and that of the nation in protecting the free flow of commerce among the states. While hard questions remain, they lie not in ethereal distinctions but in the extent of the nexus which will be required before interstate business may be subjected to the state taxing power, in the standardization of apportionment formulas in the fifty states, and in the difficulties of administration and compliance costs involved in multi-state taxation.

\section{Proposed Reforms of State Taxation of Interstate Commerce AND THE APPORTIONMENT CoNTROVERSY}

Both judicial and legislative developments stemming from the Supreme Court's decision in Northwestern suggest that the critical issue in

91 The only basis on which immunity from a tax imposed on the privilege of doing an interstate business but measured by net income could now be justified for the exclusively interstate business is the subject-measure distinction which becomes unsatisfactory when it has no relationship to the economic incidence of the tax.

92 See Hellerstein, An Academician's View of State Taxation of Interstate Commerce, 16 TAX L. REv. 159, 161 (1961).

93 See P. Hartman, State Taxation of Interstate Commerce 117-121 (1953). Undertaxation of the interstate corporation is as discriminatory as overtaxation, for the intrastate corporation would be subject to higher taxation than the interstate corporation operating within the state. See Note, State Taxation of Multistate Businesses, 74 YALE L.J. 1259 (1965). 
state taxation of interstate commerce is how interstate commerce may be taxed rather than whether it may be taxed at all..$^{94}$ The Northwestern decision itself strongly intimated, despite its apparent affirmation of Spector, ${ }^{95}$ that the significant constitutional criteria for evaluating a state tax on interstate commerce are whether the tax is "apportioned [so as not to] ... 'discriminate against or prohibit the interstate activities or ... place the interstate commerce at a disadvantage relative to local commerce" "96 and whether it is "properly apportioned to local activities within the taxing State forming sufficient nexus to support [its imposition]." ${ }^{97}$

In considering the impact of the proposed reforms of state taxation of interstate commerce, it is important to note that the congressional bill, unlike the state proposals, is severely limited in scope. The Willis Bill (officially proposed as the Interstate Taxation Act) excludes from its scope all corporations with an average annual income of over $\$ 1,000,000.98$ In addition, the bill excludes corporations in the transportation, communications, insurance, and banking industries as well as some public utilities. ${ }^{92}$ While many of the excluded corporations are in industries already subject to substantial federal and state regulation, the $\$ 1,000,000$ ceiling on the income of included corporations will effectively exempt a large part of the states' revenue sources from the protection of the bill, thus leaving the states free to tax these corporations as they do at the present. In short, many of the controversies which have plagued state taxation of interstate commerce for years-the problem of the large multi-state manufacturer, of the interstate gas or pipeline company, of the interstate transportation company-will continue to be dealt with on a case-by-case basis much as before, subject to the limitations imposed by the states on their own methods of taxation.

94 Two recent Supreme Court cases dealing with the apportionment problem (see text at notes 115-129, infra), General Motors Corp. v. District of Columbia, 380 U.S. 553 (1965), and Norfolk \& W. Ry. Co. v. Missouri State Tax Comm'n, 390 U.S. 317 (1968), the Interstate Taxation Act, H.R. 2158, dealing with a broad range of problems including nexus and apportionment, and the Multi-State Tax Compact, which also proposes a uniform solution to such problems as apportionment, are some indications of this new focus. More specifically, H.R. 2158 proposes to eliminate, for those corporations covered by the bill, the distinction between a direct net income tax and a franchise tax measured by net income; in addition, it proposes to broaden privilege tax liability to those corporations, covered by the bill, which are engaged in exclusively interstate commerce. In short, the bill proposes to eliminate the tax immunity granted the privilege of doing interstate business. See H.R. 2158, \& 501.

95 Northwestern States Portland Cement Co. v. Minnesota, 358 U.S. 450, 458 (1959).

96 Id. at 462, quoting Central Greyhound Lines v. Mealey, 334 U.S. 653, 670 (1948).

97 Id. at 452 .

98 H.R. 2158, 90th Cong., 2d Sess. § 506(3) (1968).

09 Id. $\S \S 506(1),(2)$. 
A. Nexus

The nexus issue is distinct from and logically antecedent to the problem of apportionment. Before a state may impose any tax on a foreign corporation or a non-resident, it must demonstrate some minimum connection between the state and the taxpayer or transaction taxed..$^{100}$ The first congressional attempt to deal with the nexus issue ${ }^{101}$ was limited essentially to lessening the impact of the Northwestern decision on interstate commerce. In effect it forbade a state from imposing a tax measured by net income from the sale of tangibles when the taxpayer's only activity in the state was solicitation of orders for the taxpayer or its customers. ${ }^{102}$ More comprehensive is the "business location" test embodied in the proposed Interstate Taxation Act, ${ }^{103}$ which emerged from the Willis Subcommittee's recommendations ${ }^{104}$ and was before Congress during the last session. The imposition of standard minimum nexus requirements on the states' taxing power would be a significant move towards uniformity in this area.

The nexus provisions of the bill represent a compromise between the interests of the states and those of interstate business. The states have generally resisted all congressional action restricting their tax jurisdiction, including P.L. 86-272 and the various versions of the Willis Bill. ${ }^{105}$ The business community, on the other hand, dissatisfied with what it regards as the narrowness of existing limitations on state taxing power, has urged congressional action to restrict state jurisdiction to tax further by the adoption of broad permanent establishment or business location tests of jurisdiction. ${ }^{106}$ It would restrict state taxation by excluding selling offices, inventories, warehouses, research installations, or buying offices from the definitions of such locations, depending

100 See International Harvester Co. v. Department of Treasury, 322 U.S. 340, 352-7 (1944) (Rutledge, J., concurring); Northwest Airlines, Inc. v. Minnesota, 322 U.S. 292, 308, 313 (1944) (Stone, C.J., dissenting); Barnes, State Taxation of Interstate Commerce: Nexus and Apportionment, 48 MARQ. L. REv. 218, 220-1 (1964); Developments, 75 HARv. L. REv. 953, 961-2 (1962).

101 P.L. 86-272, 15 U.S.C. § 381 (1964).

102 Id. See note 14 supra.

103 H.R. 2158, 90th Cong., 2nd Sess. § 101 (1968) adopts the "business location" test as part of the uniform jurisdictional standard. A person is considered to have a business Iocation within a state if that person "(1) owns or leases real property within the State or (2) has one or more employees located in the State." Id. $\$ 511$.

104 REPORT 1133-1212.

105 See note 18 supra.

106 Examples of the business community's attitude towards the nexus provisions of the Interstate Taxation Act can be found in the Fearings at: 55 et seq. (National Association of Wholesalers); 824 et seq. (Empire State Chamber of Commerce); 384 et seq. (Illinois Manufacturers' Association); 406 et seq. (Illinois State Chamber of Commerce); 441 et seq. (Associated Industries of New York State, Inc.). 
upon the particular business interest in question. The actual nexus provision of the bill adopts a jurisdictional standard which restricts existing state taxing powers, but nevertheless employs a business location test more favorable to the states' jurisdiction to tax than many business spokesmen had urged. ${ }^{107}$

\section{B. Apportionment}

It is in the area of apportionment, however, that the most complex problems remain. After four years of intensive study of the various methods ${ }^{108}$ employed by the states to assign the taxing state its fair

107 Hearings 1133 et seq. On October 28, 1968, Senator Abraham Ribicoff (D-Conn.) urged that the Interstate Taxation Act "be made a priority matter early in the 91st Congress." 114 CONG. REC. E9481 (daily ed. Oct. 28, 1968). He also urged that the $\$ 1,000,000$ ceiling on the average annual income of those corporations subject to the provisions of the Act be removed insofar as nexus is concerned. It is to be noted, however, that Senator Ribicoff, in his apparent attempt to increase the effective uniformity to be achieved by the Act, was not persuaded to suggest a similar change with respect to the apportionment provisions of the Act.

108 The three methods employed are: (1) separate accounting; (2) specific allocation of particular categories of income; and (3) formula apportionment of income. See generally REPORT 157-249. With separate accounting, a corporation's activities within the taxing state are regarded as though they were carried on by a distinct in-state entity, and income is computed for this hypothetical entity without reference to the remainder of the corporation's activities. REPORT 160. With specific allocation, certain classes of income are regarded as nonapportionable (with special rules governing each such class), and it involves, more than the other two methods of dividing income, a direct attempt to determine the geographical source of particular income items. REPORT 197. Specific allocation represents an effort to single out items of income that lend themselves to precise geographical location, whereas separate accounting represents an effort to single out part of a corporation. REPORT 248. Precise separate accounting is inapplicable in the many instances when a corporation's activities cannot be broken up on a state-by-state basis and specific allocation of income to a particular jurisdiction is not a sufficient basis for determining proper division of income from a "unitary business," i.e., when' the operation of the portion of the business within the state is dependent upon or contributory to the operation of the business outside the state. G. Altman \& F. Keesling, Allocation of Income in State Taxation 101 (2d ed. 1950); Lynn, The Uniform Division of Income for Tax Purposes Act Re-Examined, 46 VA. L. REv. 1257, 1261 (1960). See also Goldstein, Allocation of Income for Purposes of Corporate Taxation, 1 TAx L. REv. 149 (1946); Brookes, Allocation of Income for Purposes of Corporate Taxation-Another View, 2 TAx L. REv. 72 (1946); Goldstein, Allocation of Income for Purposes of Corporate Taxation-A Reply, 2 TAx I. REv. 80 (1946); REPORT 167.

Since separate accounting and specific allocation are unworkable as applied to many enterprises because of the interrelatedness of their interstate and intrastate operations, all jurisdictions provide for some kind of apportionment formula, Lynn, The Uniform Division of Income for Tax Purposes Act Re-Examined, 46 VA. L. REv. 1257, 1261, and the achievement of an equitable and uniform solution in state apportionment looms as the most pressing present problem in division of income. Furthermore, formula apportionment is almost universally used to divide the base of a capital stock tax since separate accounting is not authorized by any state and specific allocation plays only a minor role. REPORT 946.

The separate problem in income taxation of establishing a uniform definition of a tax base (as distinguished from apportionment which is the problem of dividing that tax 
share of a corporation's net income, the Willis Subcommittee concluded that "the present system for the division of income is characterized by diversity and complexity,"109 that the "lack of consistency in the rules for the division of income also raises the possibility of overtaxation and undertaxation ...," 110 and that since "[t]he present system for division of income is on its face overwhelming," it "will surprise no one familiar with it that in practice it works badly."111 The Subcommittee concluded that the existing system with the generalized use of a sales factor in the apportionment formulas"12 "has led to a bewildering maze of complications from which even the most eager taxpayer may be expected to recoil."113

Although the Supreme Court has virtually abstained from interfering with state apportionment formulas for nearly four decades, ${ }^{114}$ two recent decisions of the Court indicate that its long-standing policy of non-interference may be changing. In both General Motors Corp. $v$. District of Columbia ${ }^{115}$ and Norfolk o Western Railway v. Missouri State Tax Commission ${ }^{116}$ the Court struck down apportionment formulas, though only in the latter case did the decision rest on constitutional grounds. 117

The problem of apportionment is not new to the Supreme Court. In the late nineteenth and early twentieth centuries, the Court handled a number of apportionment cases arising from state capital stock and property taxes levied on enterprises engaged in interstate transportation. The Court sustained rail mileage ${ }^{118}$ and comparable apportion-

base) has not been an issue of great controversy. There has been almost no criticism of the adoption of the federal definition of taxable income as set out in the Internal Revenue Code of 1954 in the proposed Interstate Taxation Act. H.R. 2158, 90th Cong., 2nd Sess. \& 506(b) (1967).

109 REPORT 249.

110 Id.

111 Id.

112 § 15 of the Uniform Division of Income for Tax Purposes Act, which is now in use in over twenty-five states, $29 \mathrm{~J}$. TAx. 111 (1968), has the following definition of a sales factor: "The sales factor is a fraction, the numerator of which is the total sales of the taxpayer in this state during the tax period, and the denominator of which is the total sales of the taxpayer everywhere during the tax period."

113 REPORT 248.

114 On only one occasion did the Supreme Court reverse a state court decision against. a taxpayer who was challenging the state's apportionment of net income. See Hans Rees' Sons, Inc. v. North Garolina ex rel. Maxwell, 283 U.S. 123 (1931); Developments, 75 HaRv. L. REv. 953, 1014 (1962). See also Barnes, State Taxation of Interstate Commerce: Nexus and Apportionment, 48 MARQ. L. REv. 218, 221 (1964).

115380 U.S. 553 (1965). The case is noted in 33 GEo. WASH. L. REv. 785 (1965).

116390 U.S. 317 (1968). The case is discussed in Wanamaker, Supreme Court Limits Authority of States in Applying Apportionment Formulas, 29 J. TAx. 54 (1968).

117 See note 32 supra.

118 Pullman's Palace Car Co. v. Pennsylvania, 141 U.S. 18 (1891). 
ment devices ${ }^{119}$ while striking down levies which it found to result in extraterritorial taxation. ${ }^{220}$ After 1920, however, the Court grew increasingly reluctant to find fault with state apportionment formulas, ${ }^{121}$ a reluctance that continued through the 1940's and 1950's. ${ }^{122}$

It is in light of the Court's hands-off policy with respect to state apportionment formulas that the General Motors and Norfolk \& Western decisions assume an importance beyond their value as precedents. They indicate that the Court is setting standards in an area long neglected. In the General Motors case, the Court struck down a District of Columbia single-factor sales receipts formula used in its apportionment of a net income tax base. The taxpayer claimed that the levy violated both the District's statute authorizing it $^{123}$ and the due process and commerce clauses. Although the strict holding of the case was that the District had failed to levy a tax as provided for in the statute, ${ }^{124}$ the reasoning of the Court would seem to cast a shadow over the constitutionality of any single-factor formula. Since the Court found that the "geographic distribution of a corporation's sales is, by itself, of dubious significance in indicating the locus" of "either a corporation's sources of income or the social costs which it generates," 125 it would

119 Adams Express Co. v. Ohio State Auditor, 165 U.S. 194 (1897); Adams Express Co. v. Indiana, 165 U.S. 255 (1897). The apportionment in these cases included the corporation's intangibles.

120 Union Tank Line Co. v. Wright, 249 U.S. 275 (1919). The court found that the track mileage apportionment formula resulted in a disproportionately large attribution of mileage traveled by the rolling stock of a railroad in a state when compared with the actual mileage traveled, and it held the tax unconstitutional.

121 Though the Court was consistent in its constitutional approach, in practice the standards adopted by the Court for establishing a commerce clause or due process clause objection, see note 32 supra, to the state statute were such as to uphold virtually every formula. In Underwood Typewriter Co. v. Chamberlain, 254 U.S. 113 (1920), which marked the beginning of the Court's noninterventionist policy with respect to state apportionment formulas, the Court upheld a single-factor property formula over the corporation's objections to the gross disparity between the formulary and the actual value of its operations in the state. The new judicial attitude was epitomized by Maxwell v. Kent-Coffey Mfg. Co., 291 U.S. 642 (1933), where the Court sustained a North Carolina tax which allocated 99\% of a corporation's tax base to a state by means of a single-factor property formula, although the taxpayer sold less than $1 \%$ of its products in the state.

122 John Deere Plow Co. v. Franchise Tax Bd., 343 U.S. 939 (1952); Butler Bros. v. McColgan, 315 U.S. 501 (1942). In both these cases, taxpayers' efforts to establish extraterritorial taxation resulting from states' apportionment formulas met with no success.

123 D.C. CODE ANN. $\$ 47-1580$ (1961). The court quoted the pertinent portion of the statute in the following manner: "[ $[\mathrm{t}] \mathrm{he}$ measure of the franchise tax shall be that portion of the net income of the corporation ... as is fairly attributable to any trade or business carried on or engaged in within the District and such other net income as is derived from sources within the District.'" General Motors Corp. v. District of Columbia, 380 U.S. 554 (1965) (emphasis is the Court's).

124 General Motors Corp. v. District of Columbia, 380 U.S. 553, 555 (1965).

125 Id. at 561. With respect to the three-factor formula the Court said: "[T] 
appear (under the assumption that property or payroll "by itself" is also of dubious value in indicating the source of a corporation's income) that the Court's attitude toward any single-factor formula, and surely any single-factor sales formula, would be equally hostile.

The Norfolk of Western decision, which rested specifically on constitutional grounds, is the latest piece of evidence indicating a renewed judicial vigilance in controlling state apportionment. ${ }^{126}$ Here a rail mileage formula for determining the state's tax base with respect to the railroad's property was struck down, ${ }^{127}$ as the taxpayer demonstrated to the satisfaction of the Court that the method employed by the tax commissioner resulted in allocating a disproportionate amount of its rolling stock to Missouri. In holding that Missouri had attempted to overreach its constitutionally authorized taxing powers, Justice Fortas, speaking for the majority said:

Our decisions recognize the practical difficulties involved and do not require any close correspondence between the result of computation using the mileage formula and the value of property actually located in the state, but our cases certainly forbid an unexplained discrepancy as gross as that in this case. Such discrepancy certainly means that the impact of the state tax is not confined to intrastate property even within the broad tolerance permitted. ${ }^{128}$

Both General Motors and Norfolk \& Western may reflect the Court's reaction to recent criticism of its decisions in the state tax field ${ }^{129}$ and to congressional stirrings of discontent $t^{130}$ over the inequitable operation of existing state apportionment formulas. It is a healthy development: the Court has finally begun to come to grips with the most troublesome of issues in the area of state taxation of interstate commerce.-But it must be recognized that the Court can only act to strike down apportioned taxes that violate constitutional restraints imposed upon the states. As the Willis Report indicated, ${ }^{131}$ what is needed now to deal with the complex and vexatious problems of apportionment is comprehensive legislation aimed at achieving an equitable and uniform system

standard three-factor formula can be justified as a rough, practical approximation of the distribution of either a corporation's sources of income or the social costs which it generates." Id.

126 Cf. Wanamaker, Supreme Court Limits Authority of States in Applying Apportionment Formulas, 29 J. TAx. 56 (1968).

127390 U.S. 317 (1968).

$128 \mathrm{Id}$. at 327.

129 See, e.g., Pierce, Form Versus Substance, 46 VA. L. REv. 1150 (1960).

130 REPORT 248.

131 Id. at II, 1128. 
of state taxation. Apportionment problems cannot be dealt with adequately merely by erecting constitutional restraints on state taxing power. Only congressional or state reforms can achieve a comprehensive solution.

The need for a uniform system of apportionment of state taxes is widely recognized by those who are concerned with or affected by state taxation of interstate commerce, but there is sharp disagreement over how the job should be done. ${ }^{132}$ Under the Interstate Taxation Act passed by the House in May 1968, a state would be barred from applying an income tax (or capital stock tax) apportionment formula when the tax liability so computed would exceed liability as computed under the formula based on two factors-property and payroll-set forth in the bill. ${ }^{133}$

The states, however, have been opposed to the congressionally prescribed formula. ${ }^{134}$ Under the threat of federal restriction of their taxing powers, they have moved with surprising speed toward an alternative solution to the problem of state apportionment of corporate income (and capital stock). This counterproposal to the Interstate Taxation Act is embodied in the Multistate Tax Compact drafted by the Council of State Governments, ${ }^{\mathbf{1 3 5}}$ first presented for the states' consideration in 1966. ${ }^{136}$ Fifteen states ${ }^{137}$ have become regular members of the Compact and ten others ${ }^{138}$ hold associate memberships. The Compact provides taxpayers with an option to apportion income either under the method provided by state law or by use of the Uniform Division of Income for Tax Purposes Act, ${ }^{139}$ which is substantially adopted by the Compact. ${ }^{140}$

132 Compare Harriss, Economic Aspects of Interstate Apportionment of Business Income, 37 TAXEs 327, 362-63 (1959), and Studenski, The Need for Federal Curbs on State Taxes on Interstate Commerce: An Economist's Viewpoint, 46 VA. L. REV. 1121, 1181-32 (1960), with Conlon, The Apportionment of Multistate Business Income: The NCCUSL Uniform Division of Income Act, 12 TAx ExEc. 220, 229-30 (1960), Cox, The Interstate Tax Problem, 38 TAXES 417, 422-23 (1960), and Kust, State Taxation of Interstate Income: New Dimensions of an Old Problem, 12 TAX Exec. 45, 60-61 (1959).

133 H.R. 2158, 90th Cong., 2d Sess. §§ 201, 202 (1968).

134 See note 18 supra; see also 34 TAx Poucy (Nos. 7-8), 3, 4, (1967).

135 With the cooperation of the National Association of Tax Administrators, the National Association of Attorneys General and the National Legislative Conference.

13629 State Tax Rev. (No. 24) 2 (1968).

137 Alabama, Arkansas, Colorado, Florida, Hawaii, Idaho, Illinois, Kansas, Missouri, Nebraska, Nevada, New Mexico, Oregon, Texas, and Washington. Action is pending in Michigan, New York, Pennsylvania, and Wyoming. 29 J. TAx. 111 (1968).

138 Alaska, Arizona, California, Indiana, Massachusetts, Montana, North Dakota, Pennsylvania, Utah, and West Virginia. 29 State Tax Rev. (No. 24) 18 (1968).

139 The Uniform Division of Income For Tax Purposes Act is a proposal, worked out by state tax administrators, lawyers, and accountants, aimed at achieving greater uniformity 
In effect, this would add to the property and payroll factors a receipts factor now used by all the states with net income measures. The Uniform Act's formula, already in use in more than one-half of the states with income measures, ${ }^{141}$ provides for apportionment of business income by the use of such a three-factor formula. ${ }^{142}$

The primary consideration in the current concern over apportionment is the achievement of uniformity. ${ }^{143}$ The need for federal legislation to achieve this goal, however, must be re-evaluated in light of the adoption by a rapidly increasing number of states of the Multi-State Tax Compact and the enactment by the states of the Uniform Division of Income for Tax Purposes Act. It can no longer be said, as it was four years ago, that "the conclusion is inescapable that the voluntary adoption by the States of any kind of uniform system is a slow and halting process if not a virtual impossibility."144 The unprecedented state willingness to cooperate in face of the possibility of federal curbs on their taxing power seems at this point to be achieving the very uniformity at which the congressional bill is aimed. Furthermore, since the state' proposals are broader in scope than the congressional bill, a greater degree of uniformity would be achieved by their enactment.

Apart from the substantive differences between the two proposals, a state solution to the problem is probably preferable. When the states are willing, as they now appear to be, to cooperate voluntarily in rationalizing the national system without the direct interference of the federal government, the imposition of a federal standard upon the states for

in state taxation of interstate commerce. It was accepted in 1957 by the National Conference of Commissioners on Uniform State Laws, approved by the American Bar Association, and adopted by twelve states, see note 141 infra, before it was in essence incorporated in the Multi-State Tax Compact where it has received even more widespread acceptance.

140 Article III of the Multi-State Tax Compact gives the taxpayer the option to apportion and allocate with reference to state law or with reference to Article IV of the MultiState Compact, which adopts, practically verbatim, the Uniform Division of Income for Tax Purposes Act.

141 The following states have adopted the Uniform Division of Income for Tax Purposes Act: Alaska, Arkansas, California, Hawaii, Idaho, Indiana, Kansas, Kentucky, Michigan, Montana, Nebraska, New Mexico, North Carolina, North Dakota, Oklahoma, Oregon, Utah, and Virginia. 29 J. TAx. 111 (1968).

142 UNIFORM DIVISION OF INGOME For TAX PuRposes AGT \& 9.

143 REPORT 128-133. Indeed, the importance of uniformity as a goal has long been recognized. Id. at 129. "All methods of apportionment of trading profits are arbitrary .... There is no one right rule of apportionment .... The only right rule of procedure is a rule on which the several states can and will get together as a matter of comity"National Tax Association, Report of Committee on the Apportionment Between States of Taxes on Mercantile and Manufacturing Business, 1922 ProceEDINGs 198, 201; REPORT 130or which Congress will impose on the states. Hellerstein \& Hennefeld, State Taxation in $a$ National Economy, 54 HARv. L. REv. 949, 962 (1941).

144 REPORT 133. 
the purpose of achieving the same result is not only superfluous but also tends to discourage the states from taking the kind of initiative that adds vitality to the federal system.

Of course, uniformity is not the only goal. Consideration must be given the relative merits of the congressional and state formulas. The Subcommittee's recommendation of a two-factor rather than a threefactor formula was based primarily on two conclusions: the receipts factor seemed to provide the most severe compliance and administrative difficulties, ${ }^{145}$ and it appeared to make very little difference from the point of view of state revenue whether a three-factor or a two-factor formula was used.146 The states' opposition to the Interstate Taxation Act's apportionment provisions, on the other hand, has been justified on several grounds. ${ }^{147}$ The states, in their understandable concern with upsetting the balance of federalism, contend that they, and they alone, ought to prescribe the formula governing the apportionment of income to the states. ${ }^{148}$ Moreover, notwithstanding the Subcommitee's conclusion that the abandonment of the receipts factor would have little revenue significance, many states fear a diminution in their tax revenues as a result of the bill.149 Finally, those states fearing a loss of revenue feel that the Subcommittee had ignored the claim of the market state to a fair share of the tax revenues from interstate businesses enjoying the opportunities and protection which those states afforded. ${ }^{150}$

145 Id. at $247-9$.

146 Id. at $560-3$.

147 See note 18 supra. See generally, 34 TAx PoLIcy (Nos. 7-8) (1967); Conlon, The Apportionment of Multi-State Business Income: The NCCUSL Uniform Division of Income Act, 12 TAx ExEc. 220 (1960); Cox, The Interstate Tax Problem, 38 TAXes 417 (1960); Kust, State Taxation of Interstate Income: Nezw Dimensions of an Old Problem, 12 TAX ExEc. 45 (1959).

148 The Honorable William H. Avery, Governor of Kansas, strongly expressed this concern with the federal balance: "At the outset, Mr. Chairman, I want to make it clear that the State of Kansas is unequivocally opposed to H.R. 11798 and any other attempted Federal intervention into the tax and fiscal policies of our State . . . [I]t is the belief and the conviction of the executive and legislative branches of the government of the State of Kansas that bills such as H.R. 11798 are erosions of the principles of federalism which have served as a basis for our government since its inception." Hearings 1220.

149 Francis Hillard, Member of the Wyoming Board of Equalization, declared: "Wyoming is very much a consumer State and has very little industry. Thus we believe the deletion of a sales factor was a grave mistake and tremendously detrimental to such states as Wyoming . . . [C]ontrary to your findings, the elimination of this factor would make a tremendous difference to the States like Wyoming . . ." Hearings 715, 716.

Governor Grant Sawyer of Nevada, on behalf of the Western Governors' Conference, stated: "[E]nactment of H.R. 11798 [more recently H.R. 2158] or similar legislation would have a profound impact on the revenues, revenue structures, and hence the economy of each of the several States represented in the Western Governors' Conference." Hearings 265.

150 Governor Grant Sawyer of Nevada, on behalf of the Western Governors' Conference, stated: "I might observe that it seems ironic that the bills you have before you give such 
The primary argument made in favor of dropping the receipts factor from the congressional formula is that the receipts factor is the source of the complexities of the present system of apportionment resulting in "noncompliance and in the inequities which come with a tax system in which formal requirements have been abandoned."151 The receipts factor, varying in form from state to state, was found to add unjustifiably to record-keeping costs. ${ }^{152}$ The fear that such costs would become burdensome if there were rigid enforcement of the three-factor formula led the Subcommittee to recommend the two-factor formula which had the virtue of simplicity. ${ }^{153}$

It would seem, however, that if Congress or the states were to adopt a uniform apportionment formula (regardless of the particular formula adopted), many other complexities would disappear. First, since there would be only one standard formula applicable to the apportionment of all state net income and capital stock taxes, the costs and difficulties of complying with a multitude of different receipts formulas would be diminished substantially. ${ }^{154}$ Second, the inequities resulting from a variety of apportionment formulas inconsistently enforced would no longer exist if there were but one formula, whether designed by the states or by Congress. Third, the Subcommittee's argument that smaller interstate businesses would be subjected to an onerous and costly burden by the adoption of a formula with a receipts factor ${ }^{155}$ loses much of its force in light of the sales tax provision of the Interstate Taxation Act, ${ }^{156}$ which would require a great many interstate vendors to maintain the very records that the income apportionment provision theoretically makes unnecessary. ${ }^{157}$ In short, the Subcommittee's solution is in

short shrift to the contribution the market State makes in the production of income. Your stated interest lies in the protection of businesses engaged in interstate commerce. Yet for purposes of taxation these bills ignore or give very little weight to what is essential to such a business-the availability of markets in States other than the State in which it has a "business location." "Hearings 266.

151 REPORT 334, 384.

$152 I d$. at 382 .

$153 I d$. at 1135 .

154 Hearings 1074.

155 REPORT 528, 563. The Report acknowledges that "For most of the larger interstate companies ... it would appear that the cost of computing a sales factor can be kept within reasonable limits no matter which of the factors should be adopted, although there are undoubtedly some exceptions to the general rule." Id. at $\mathbf{5 2 8 .}$

156 H.R. 2158, 90th Cong., 2d Sess. \$ 301 (1968), permits the states to impose a sales tax or to require that a seller collect a use tax with respect to an interstate sale only if the destination of the sale is in that state or in the state in which the tax is required to be collected.

157 Any state enacting the federally prescribed sales and use tax law with the sales destination test would require the interstate vendor to record the destination of the sales made, in which case the computation of a sales factor in an income or capital stock tax 
many respects no less complex nor less costly than that of the states, and it would appear that in the face of strong state sentiment for retaining the receipts factor, the Congress should re-evaluate the House's rejection of the three-factor formula before imposing significant structural changes on the existing state apportionment methods.

As for the revenue consequences of adopting the two-factor formula, serious doubts may be raised about the Subcommitee's conclusion that the choice of a two- or three-factor formula would have little impact on state revenues. ${ }^{158}$ This conclusion is unwarranted because the Subcommittee Report measures revenue significance by the percentage impact on all fifty states' total tax revenues. ${ }^{159}$ But the differential impact of the two- and three-factor formulas on any single state's net income tax revenue may be enormous: North Dakota's corporate income tax would be reduced by 47 per cent; Idaho, the District of Columbia, and New Mexico by over twenty per cent; and six other states by ten to nineteen per cent. ${ }^{160}$ Dollar losses would also be significant in many cases: Mississippi and Montana would lose half a million dollars each, Minnesota about $\$ 1.7$ million and New York $\$ 13$ million. ${ }^{181}$ The heavy industrial states would stand to gain from the introduction of a standardized two-factor formula. ${ }^{162}$ Viewed in terms of its effect on the revenue which particular states derive from manufacturing and mercantile companies, the choice of a formula would in some cases have substantial effects. ${ }^{163}$

In short, to evaluate the revenue impact of varying apportionment formulas by the impact upon total revenues from all state taxes is to dilute the results and underestimate the revenue effect upon the states. The adoption of a two-factor rather than the three-factor formula would tend to upset the present distribution of corporate income tax revenues to the detriment of the market states. It would thus tend to divert revenue to those states with the greatest concentrations of labor and capital.

Whether there ought to be such a redistribution of tax revenue among the states may depend on the extent to which one associates the selling

apportionment formula would not be a great additional burden. It must be recognized, however, that many manufacturers and wholesalers sell only goods which are ordinarily not subject to a state sales tax and would therefore not be required to keep these records in the absence of a sales factor in the formula. Hearings 1074.

158 See, e.g., Hellerstein, Allocation and Nexus in State Taxation of Interstate Businesses,

20 TAx L. REv. 259, 267-76 (1965); 34 TAX Policy (Nos. 7-8) 3,4 (1967).

150 REPORT 545; see Hearings 1072-3.

160 REPORT Chatt 16-A, 540-1.

161 RePort A498-8; see Hearings 1073.

162 REPORT A493-503; see Hearings 1073.

163 REPORT 539. 
process with the production of income. One commentator succinctly expressed the "economic" justification behind the desire to abandon the sales factor in the computation of a state's income tax base:

One basic principle lies at the heart of it: "Income may be defined as the gain derived from capital, from labor or from both combined ...." Accordingly, the ideal formula never includes a receipts factor. ${ }^{\mathbf{1 6 4}}$

Irrespective of the questionable analytical validity of this proposition, ${ }^{165}$ when one turns to the actual operations of an interstate business in the marketplace, the influence of the sales process on the income of a corporation would appear to extend beyond the factors of capital and labor which are committed to sales. The large profits derived from sales of goods in any state may be due to population increases, a rising standard of living, the general expansion of our economy, and a number of other factors which may be only remotely related to the capital and labor a corporation allocates to selling in that state. ${ }^{166}$ Moreover, the ten billion dollars spent annually for advertising to exploit the marketplace would seem to indicate that the market qua market has an economic importance which may far exceed the value of the property and payroll located in a particular taxing jurisdiction. ${ }^{\mathbf{1 6 7}}$ From this point of view, an apportionment formula which failed to include a sales factor would tend to distort the tax base adversely against the economic contribution made by the market state in the income creation process since it would be only fortuitous if the distribution of a corporation's payroll and property were identical to the distribution of its sales.

In the final analysis, practical considerations of optimum revenue distribution among the states may be the best justification for retaining the three-factor formula favored by the states rather than adopting the congressional two-factor formula. Only if there is a receipts factor will the market state in which an interstate business has little property and few employees be able to share in the tax revenues from the interstate

164 Barnes, State Taxation of Interstate Commerce: Nexus and Apportionment, 48 MARQ. L. REv. 218, 223 (1964). Barnes continues: "For manufacturing, it might be tangible productive property (capital) and payroll (labor). For merchandising, it might be inventory (capital) and payroll (labor). For fnancing, it might be intangibles (capital) and payroll (labor). For transportation, it might be tangible property (capital) and payroll (labor)." Id.

165 P. SAmuelson, Economics, AN Introductory ANAlysis, pts. 3, 4 (5th ed. 1961).

106 Hellerstein, Allocation and Nexus in State Taxation of Interstate Businesses, 20 TAx L. REV. 259, 274-5 (1965). Professor Hellerstein writes: "For example, during World War II the prices of second hand cars and the profits from their sale increased sharply in this country, not because of added capital or labor costs, but simply because new cars were no longer produced." Id.

$167 \mathrm{Id}$. at 276. 
business which exploits its market. The presence of a market also indicates the presence of people with governmental needs. One of the primary sources of state tax revenues to meet these needs are corporate income and capital stock taxes. ${ }^{163}$ Another argument, then, in favor of retaining the receipts factor is that it distributes tax revenues where they are needed to meet the costs of government. Despite the simplicity of this argument, it is a compelling one if one considers revenue distribution in terms of need only, ignoring, for the moment, the question of recompense for benefit conferred. The states are currently facing severe financial crises, with increasing pressures on them to meet burgeoning demands for schools, roads, hospitals, welfare, and police and fire protection, and to expand their roles in dealing with housing, juvenile delinquency, mental health and other problems. These are demands which must be met by market states no less than by industrial states. The inclusion of a sales factor will permit the market states to obtain at least their present share of the tax revenues from interstate business-revenues which the abolition of a sales factor would substantially reduce. ${ }^{169}$

Only if there is a receipts factor will the market state be recompensed by interstate business for the protection of its laws and the benefits of its market. One critic of the congressional proposal expressed this view strongly:

. . H.R. 11798 [now H.R. 2158, as amended] ignores a very basic and fundamental principle recognized by the courts, and that is, the marketing State should be able to collect its fair share of the taxes for the contributions it makes to the final sale of the products. The State of destination provides the marketplace for the multistate business to operate. It creates the economic climate conducive for business operations. It accords the multistate businesses the many tax-supported services and protection. Yet, by the application of the business location test and state of origin test set forth in the bill, the marketing state may not in every case assert its jurisdiction. The use of independent contractors in lieu of employees who operate their business from personal residence is just such an example. ${ }^{170}$

108 Corporate income taxes produce about $9 \%$ of the total revenue of the states which have such taxes. REPORT 108, Table 5-3 110-111. Capital stock taxes produce about $3 \%$ of the total revenue of the states which have such taxes. REPORT 909, Table 29-3 910.

169 Hellerstein, Allocation and Nexus in State Taxation of Interstate Commerce, 20 TAX L. Rev. 259, 269 (1965).

170 Hearings 1008 (testimony of Allen Marutani, Special Deputy Attorney General of Hawaii); cf. 86th Cong., Ist Sess., Senate, Comm. on Finance, State Taxation of Interstate 
Finally, it should be noted that the states in which large permanent installations of interstate businesses are located, the states in which manufacturing and warehousing are carried on, the states in which the heavy concentrations of executive and administrative personnel are found presently enjoy a heavy weighting in state apportionment formulas. Hence, even with the general use of a receipts factor, these states derive the major share of existing tax measures. ${ }^{171}$ It seems entirely justifiable to include a sales factor, which has a weight of only one-third in determining the total tax base, which can be supported both in terms of economic benefit conferred by the taxing state and in terms of optimum revenue distribution, and without which the market state would suffer substantial losses in corporate income and capital stock tax revenue.

\section{Summary and Concluston}

Roadway Express, which narrows the tax immunity afforded the privilege of doing interstate business to insignificance, indicates that exclusively interstate commerce may be taxed either if a state tax statute prescribes a direct income tax as in Northwestern or if the state court is careful in distinguishing its statute from the Connecticut statute struck down in Spector. An analysis of other state statutes suggests that the approach followed in Roadway Express may be used by other states as well, to broaden their taxing powers to reach exclusively interstate businesses. At the same time, such an analysis demonstrates that the privilege concept is no longer a relevant frame of reference for dealing with the critical issues confronting state taxation of interstate commerce.

Once it is recognized that interstate businesses may legitimately be taxed by the states, the crucial issue becomes the method of state taxation. One of the most complex problems concerns state formulas apportioning income or capital stock of multi-state corporations among the

Commerce, Hearings on S. 2524 at 31-32 (1959), where Senator Kenneth B. Keating (R-N.Y.) said:

A corporation which employs capital and labor and operates facilities within a State is an integral part of that State's economy and receives a variety of protective and other services for which the State should be compensated. Since these services directly relate to the income-producing activities of the company, a tax on income allocated to these activities is patently reasonable. On the other hand, a company which does not have a place of business in a State does not receive any benefits from the State which relate to its income producing activities. Such a State does not put out a fire on the company's premises, it does not insure its employees against injury on the job, it does not protect its warehouses, it does not maintain the streets and highways or subways and utilities needed for the company's functioning. The fact that the property of such a foreign corporation is delivered to one of its citizens may justify a sales or use tax, but it does not justify a tax on the net income of the company.

171 REPORT A477-509; Hellerstein, An Academician's Diew of State Taxation of Interstate Commerce, 16 TAx. L. REv 159, 175 (1961). 
states. The diversity and inconsistency in present state formulas have led to inequities in the system. Although the Supreme Court has recently indicated a renewed concern with the problem, what is needed is a comprehensive solution beyond the purview of the Court. Two proposals, the congressional Interstate Taxation Act and the Multi-State Tax Compact, support differing uniform methods of apportionment. Since congressional fears of high costs of compliance with the threefactor formula are probably exaggerated, and since the revenue effects on the states of the adoption of the congressional two-factor formula would be considerable, the three-factor formula, which allows the market state to tap larger sources of revenue from interstate business, is preferable. 